\title{
La utopía traductora
}

\author{
Rodolfo Alonso ${ }^{\bullet}$
}

Convocado cierta vez por un periódico especializado para evaluar distintas versiones de un poema extranjero, lo primero que acudió a mi mente fue aquella afirmación del sagaz Pedro Henríquez Ureña acerca de que cada generación debe traducir a su Homero. Es decir, entre otras posibles implicancias, que la palabra es también histórica, y que cada camada que se precie debe hacer por sí misma la experiencia de apropiarse verbalmente de sus clásicos, de inventar a sus clásicos.

Cuando un científico tan riguroso como Noam Chomsky define a toda lengua como "cierta relación entre sonido y sentido", quizás inconscientemente, porque un artista tan cabal como Paul Valéry ya se le había adelantado casi con las mismas palabras en relación con el poema, nos está dando también una buena pista para el texto literario (después de todo, culminación de una lengua, y muy especialmente para el poema que, cuando se logra, no es otra cosa que un ser vivo de lenguaje, autónomo, soberano). Y tan encarnado en su lengua que proponerse verterlo a otro, no dejará de ser siempre una utopía. Y sin embargo, por necesidad o por placer, y aun por amor, seguimos intentando traducir. Al hacerlo, salvo milagros que aquí también son improbables, inevitablemente se deberá optar entre el sonido y el sentido. (Aun en el caso de las lenguas más afines, donde corremos riesgos por homologación, fácil abismo). Pero el intento siempre deberá tender a crear otro ser autónomo de lenguaje, no menos similar o emparentado.

\footnotetext{
- Poeta, traductor, ensayista y ex editor argentino. Es una voz reconocida de la poesía latinoamericana contemporánea. Fue el más joven de la legendaria revista de vanguardia "Poesía Buenos Aires". A partir de "Salud o nada" (1954), publicó más de 25 libros, la mayoría de poemas pero también de ensayo y narrativa. Primer traductor de Fernando Pessoa en América Latina (1961). Tradujo también a muchos otros importantes autores del francés, italiano, portugués y gallego, entre ellos Cesare Pavese, Giuseppe Ungaretti, Paul Éluard, Marguerite Duras, Eugenio Montale, Carlos Drummond de Andrade, Jacques Prévert, Dino Campana, Antonin Artaud, Guillaume Apollinaire, Pier Paolo Pasolini, Charles Baudelaire, Murilo Mendes, Antonin Artaud, Manuel Bandeira, Rosalía de Castro, Paul Valéry, Olavo Bilac, Stéphane Mallarmé, André Breton, etc. Antologías y libros suyos fueron publicadas en Argentina, Bélgica, Colombia, España, México, Venezuela, Francia, Brasil, Italia, Cuba y, próximamente, Chile. Escribió textos para cine, como el célebre cortometraje "Faena" (1960). Premio Nacional de Poesía (1997), junto a Juan Gelman. Orden "Alejo Zuloaga" de la Universidad de Carabobo (Venezuela, 2002). Gran Premio de Honor de la Fundación Argentina para la Poesía (2004). Palmas Académicas de la Academia Brasileña de Letras (2005). Premio Único de Ensayo Inédito de la Ciudad de Buenos Aires (2005). Premio Festival Internacional de Poesía de Medellín (Colombia, 2006). Entre sus libros más recientes se destacan La voz sin amo, con prólogo de Héctor Tizón (Ediciones de Medianoche, Zacatecas, México, 2008); Il rumore del mondo, con prólogo de Juan Gelman (Ponte Sisto, Roma, 2009); El arte de callar, con palabras de Juan José Saer (El Perro y la Rana, Caracas, 2009); Ser sed, con prólogo de Juan Gelman (Arte y Literatura, La Habana, 2009); La vida entera, con prólogo de Juan Gelman (Poesía de Paper, Palma de Mallorca, España, 2009); Poemas pendientes, con prólogo de Lêdo Ivo (Alción Editora, Córdoba, 2010).
} 
Como ven, la tarea que me fue encomendada era altamente incierta, y sólo hubiera podido responderse - a mi modesto entender- intentando una enésima traducción, ya que toda utopía es felizmente inalcanzable, dichosamente interminable. Pero, de todos modos, inclusive para mí, vayan dos consejos. Uno, que siempre se acompañe el texto original de cada poema traducido. Otro, que recordemos todos la indiferencia de un Goethe y la risa sarcástica de un Schiller nada menos que para con la Antígona de Hoelderlin, sin duda paradigma de toda utopía traductora (y que dio origen a uno de los libros más memorables del impar George Steiner: precisamente Antígonas), ya que no se proponía apenas trasladar el texto a su idioma sino tomar en cuenta al hacerlo no sólo las distintas situaciones cronológicas y por lo tanto socioculturales de ambos protagonistas, sino hasta las limitaciones inconscientes que el genial poeta alemán intuía en Sófocles como persona, para con su propio idioma, en el preciso momento original.

\section{El doble fondo}

Cuando más fácilmente traducible a otra lengua distinta resulta el poema, ¿no estará demostrando palmariamente con ello una mayor carencia en relación con su propia lengua?

\section{Sonido y/o sentido}

Todo auténtico poeta esconde a un crítico, llegó a afirmar nada menos que Baudelaire. El que había en Paul Valéry, sin duda uno de los más lúcidos creadores capaces de reflexionar hondamente sobre su arte, logró aludir al poema como "esa oscilación prolongada entre el sonido y el sentido". Con toda la desconfianza que, salvando las distancias, ambos experimentamos con respecto a cualquier pretensión tajante en estas lides, pude sentir que el autor de El cementerio marino había alcanzado allí una buena aproximación.

Finalmente como toda lengua humana, aun en su expresión más cotidiana o íntima, hasta el poema logrado — ser soberano, autónomo de lenguaje, cuando cuaja - se mantiene ineludiblemente en tensión frente a ambos polos. Pero no de cualquier modo, claro. Como dijo también el mismo Valery: "En el arte, nada ha sido logrado todavía hasta que no se alcance el canto". A lo cual supo agregar, igualmente, él mismo: "Es un prejuicio muy notable creer que el sentido de un discurso posee mayor dignidad que el sonido y que el ritmo".

Fue nuestro inefable, indeleble César Vallejo, después de afirmar sin sombra de duda lo que tanto me he permitido reiterar: todos sabemos que la Poesía es intraducible", quien llegó a aducir, como dando un ejemplo para él negativo, que "Se puede traducir solamente los versos hechos de ideas". Claro, los otros, los pocos, están inescindiblemente encarnados, hechos "gloria de la lengua", como bien sabía Dante. Por eso, suelen ser raros los autores que, aunque generalmente honrados, logran aproximarse a esa instancia en la cual, según el ya citado Valery, "se logra la temperatura a la cual se producen las transformaciones". Que no se alcanza siempre, es claro. Porque ni los muy altos y sólo pocos de los poetas que en el mundo han sido lo lograron, tampoco, siempre. 
Así afirmó otro artista de fondo, de raza, el imperturbable Pierre Reverdy, que "La Poesía es la forma más ardiente y más imprecisa de la vida. Después, ceniza". A ese nivel, a esa temperatura de existencia y de lenguaje, para él "La Poesía es a la vida como el fuego a la madera. Emana de ella y la transforma. Durante un momento, un breve momento, engalana la vida con toda la magia de las combustiones y las incandescencias". Pero sólo un momento. No siempre. No, ¡ay!, para siempre.

Esa alta lección de intimidad y de grandeza, ese fruto sagrado de nuestra propia condición, que es también la de una llama en el viento, nos exige mantenernos a su altura, en su propia combustión, en su ineludible tensión interna. Y no se procede ante esas elevadas temperaturas sin que de ello queden huellas, residuos, rebarbas. Huellas de una tensión y de un combate, huellas de taller y de misterio, de fraternidad y extrañamiento. Como esos lugares a la vez inquietantes y entrañables adonde nos conduce, para luego dejarnos allí, abandonados a nuestra propia suerte, la bendita lengua madre.

\section{Del lado de Cervantes}

No una sino varias veces me tocó aludir últimamente, ocupándome de versiones al castellano de poesía extranjera, a ese doble círculo de ansiedad en que dicha labor se inscribe, y al que me vi tentado de intentar definir como la utopía traductora. Porque, si por un lado resulta casi absolutamente imposible pretender trasladar a otra lengua un poema logrado que, para serlo, ha de estar precisamente fundido en forma inescindible ( $y$ dichosa) con la suya, hecho un solo cuerpo con ella, por el otro resulta también altamente deseable, casi atávica y en muchos sentidos sumamente fecunda la recurrente tentación de traducirlo.

En nada de ello pensaba cuando me topé, no hace mucho tiempo, mientras me daba el gustazo de releer - con enorme felicidad, con infinito placer- el Quijote, con un inesperado, por olvidadizo, argumento de peso a mi favor. En el memorable capítulo sexto donde se trata del meticuloso escrutinio que de la biblioteca del protagonista hacen dos amigos de su aldea, sin duda un maravilloso ejemplo de la más acerada, ingeniosa y poco complaciente crítica literaria, Cervantes pone en boca del cura entre inquisidor y adicto estas agudas conclusiones: "y lo mesmo harán todos aquellos que los libros de verso quisieren volver en otra lengua: que, por mucho cuidado que pongan y habilidad que muestren, jamás llegarán al punto que ellos tienen en su primer nacimiento". Tras de lo cual sólo me restaría agregar, no sin satisfacción y acaso en el aire de Sancho: "Quod erat demostrandum".

Lo que confío no haga más que devolvernos a una conciencia a la vez más amplia, oscura y honda de la poesía pero también del lenguaje, desde el más exquisito al felizmente cotidiano, vivo en la historia y desde la historia de los hombres que lo hablaron y lo hablan, pero capaz también de la más temblorosa intimidad. La poesía que no es quizá otra cosa que lengua soberana y autónoma pero, a la vez, indisolublemente, también lengua que otros hablaron e hicieron, al hablar, con su vivir. Y que debería hoy, también, volverse legítimamente lengua viva, individual y general, de uno y de la especie. Así sea. 


\section{Entre sonido y sentido}

Sólo si cayéramos en la trampa de tomar por simple ingenuidad la demoledora lucidez con que Paul Valéry supo aludir al poema como "esa oscilación prolongada entre el sonido y el sentido", sería posible obviar que semejante artista pudo adelantarse así a lo que un científico como Noam Chomsky iba a generalizar, mucho más tarde, definiendo a toda lengua como "una particular relación entre el sonido y el sentido". De lo cual, entre otras muchas y fecundas derivaciones, no es menor la de comprobar que aun cuando la más alta poesía se arroje hacia sus límites nunca dejará de estar, así sea secreta y misteriosamente, vinculada con el mismo lenguaje que hablan los hombres.

Oscilar entre la carnalidad del sonido y la intensidad del sentido, presintiendo si es que no buscando allí precisamente lo esencial de la poesía y del lenguaje implica, ineludiblemente, también asumir con seriedad tanto los momentos felices, más logrados, como aquellos otros en que esa ineludible oscilación nos arroja, fatalmente, de uno u otro lado. Que bien pueden resultar diferentes abismos: la grandilocuencia, por ejemplo, en los apasionamientos sonoros de linaje romántico o parasurrealista, o recaer en el mero conceptualismo, prosaico en el peor sentido.

Porque, si mantenerse en el filo mismo de la poesía y de todo lenguaje, entre la música y el argumento, como ya dije es sin duda prueba de cabal entereza intelectual, la verdadera línea de alta tensión aspira a alcanzar esos escasos momentos relevantes en que ambos elementos, sonido y sentido, parecen consumarse en una llama única.

Aunque quizás hay también una música de la mente, un sonido del sentido. "Pues la idea que hay detrás de un poema es siempre inferior al sentido del poema; el sentido depende tanto de la estructura musical como de la estructura intelectual". Y no es casual ni que quien así opine sea nada menos que Eliot, ni que quien esto escribe lo haya elegido, junto con Valéry, como su testigo de descargo. ¿Quién podría acusarlos de oníricos, verbalistas o extrovertidos?

\section{Delicias de la palabra}

Quizá nunca como frente al dificultoso, insatisfactorio contacto con los inefables poetas árabes que hemos llegado a tener quienes no gozamos de su idioma, se me ha vuelto tan patética, dolorosamente vívida la imposibilidad de traducir del todo a otra lengua ajena una gran poesía, plenamente encarnada por lo tanto en la suya. Y, a la vez, no con menor angustia, la irremediable tentación, la absoluta necesidad de intentarlo.

Como ocurre con otras grandes culturas del planeta (pensemos por ejemplo tan sólo en India, Japón o China), el pesado lastre de las circunstancias en gran medida culturalmente heredadas nos hace percibirlas por lo menos como distantes. Y sin embargo... Y sin embargo es en lo más límpido de nuestra propia lengua —como todas también felizmente mestiza - donde las palabras de claro linaje árabe relumbran con resplandeciente y sonora belleza: áloe, almohada, acíbar, alfombra, alondra, alumbre, azufre, acequia, aljibe, aljaba, almena, azúcar, alcachofa, y mil más. Y fue en los altos cerros del oriente antioqueño, en esa misma Colombia 
cuyo pueblo sigue hablando con expresividad y soltura uno de los castellanos más caudalosos y ricos que conozco, donde me descubrí paladeando, maravillado, esa resplandeciente palabra: almojábana, que allí designaba una dorada pieza de panadería local Cuando no es en los prefijos de mi propio apellido, o en el de mi abuela paterna, Abuin, donde la riqueza y esplendor de la lengua árabe podrían asaltarme como una presencia y como un atavismo.

Porque fue gracias a un maravilloso traductor español: Emilio García Gómez que, desde muy joven, sentí que podía atisbar la sensual y grave belleza de los poemas arábigo-andaluces (que el cante jondo ya me había hecho aprehender por empatía, casi de manera intuitiva, saludablemente inconsciente, y que nuestro Rodolfo A. Borello iba a investigar, en los orígenes mismos de la lírica peninsular, con las jarchas andalusies).

Testimonios de la enorme diversidad y riqueza de las lenguas todas de los hombres, cada una de ellas un tesoro único y a la vez disponible para todos, que en Bruselas el especialista Edouard Tarabay (autor de una excelente Antología de la literatura árabe contemporánea en tres tomos, vertida por él al francés) me hizo incluso más patente al demostrarme gráficamente las diferentes fonéticas (tonadas, diríamos nosotros) con que cada comunidad, cada comarca enciende a sus palabras, incluyendo el mismo nombre del autor. ¿Cómo iba a asombrar eso en un pueblo que, como el de los árabes, dicen que tiene hasta diez mil palabras diferentes para decir simplemente caballo?

\section{¿Quién le teme a los clásicos?}

Si alguna vez intuí, como prueba de fuego con respecto a una gran poesía, precisamente su dificultad para ser traducida a otra lengua, diferente de aquella en la que había logrado encarnar como ser vivo de lenguaje, soberbia y orgánicamente autónomo, la del límpido, entrañable italiano Mario Luzi (nacido nada menos que en Florencia, el mismo ańo en que se desencadenaba la primera guerra mundial, y fallecido no hace mucho) resulta en forma explícita un paradigma, un testimonio, una evidencia.

La sobria, voluptuosa musicalidad de esos versos perfectos, no se agota sin embargo en sí misma. Sonido y sentido, esa carne viva de lenguaje, obviamente intransferible, con ser bellamente modulada, nunca deja de contagiarnos al mismo tiempo la presencia de un yo y un mundo hondamente aprehendidos.

¿Por qué no animarnos todavía a seguir llamando clásicos a estos modernos poemas, transidos y cantados, donde el oído atiende directamente al corazón de la belleza en el dominio de una humanísima experiencia humana, en la tensión efímera y eterna del tiempo y la memoria de nuestra condición, ineludible, volátil e indeleble?

Toda traducción, entonces, toda palabra acaso, no dejarán, nunca, de ser, para mí, y temblorosamente, al mismo tiempo que sincero homenaje e intención frustrada, digna y patéticamente, aproximativas. 


\section{Un poeta de Egipto}

¿Dónde podía haber ocurrido, sino en el VII Festival Internacional de Poesía y en Medellín? Jean-Clarence Lambert me invita a colaborar con él en la traducción de un poeta árabe, con quien ya nos habíamos conocido y que debe leer esa misma noche. Acepto muy honrado, y no sólo por gusto. En el cuarto del autor donde, sin proponérselo, como al descuido, relumbra la belleza de un plato blanco con rotundas uvas negras rociadas con algunas gotas de agua, que traen algo de frescura a la tarde de calor, trabajamos intensamente en la traducción de un poema de Ahmad Abdel-Muti Hiyazi. Mientras él nos observa, Jean-Clarence me da su versión en francés y escucha mi propia sugerencia en nuestro idioma que, después de múltiples consultas, agotando entre los tres todas las dudas, todas las posibilidades, voy pasando al papel para evaluar su forma escrita.

Cae la tarde, lentamente, como suele hacerlo en el trópico. Sin darnos cuenta, a pura magia de las circunstancias, todos lejos de casa, quizás estamos reviviendo algo así como un implícito homenaje al espíritu de la memorable Escuela de Traductores de Toledo. Cada palabra viene y va, rodando entre su sentido y su sonido, se la paladea y se la interroga, en un vaivén afín e involuntario, racional e instintivo, de idioma en idioma, de hombre en hombre. Esa noche, en el vasto anfiteatro emplazado en lo alto del cerro Nutibara, ante la reiterada multitud de muchos miles de personas ávidas de compartir poesía, Hiyazi dice el poema original en su propia lengua con una encendida, incontrastable sensualidad mucho más que musical, y yo mismo experimento, vivamente conmovido —al leer a continuación nuestra versión al castellano-, el contacto con la corriente viva del lenguaje encarnado, que nos recorre a todos, en el proscenio o en las gradas.

Recordé cuando, sentados en la misma mesa con algunos brillantes intelectuales del África negra, usando el francés como vehículo, Hiyazi había aludido con sutil ironía a su condición de árabe con aspecto de blanco. El también nos dijo, en otra ocasión, allí mismo, algo así como que quienes habíamos quedado fuera de la omnipresente globalización debíamos defender, encarnar una imagen de la poesía que se estaba perdiendo, ligada a la sensualidad del lenguaje humano y ajena a la seca conceptualización tanto como a la hipertecnología dominante. Me parece una propuesta excelente.

A mi solicitud, amigos de Medellín me informan que Ahmad Abdel-Muti Hiyazi es uno de los poetas más destacados de Egipto, que trabaja en el departamento de estudios arábigos de la Universidad de París y que publicó cinco libros de poesía, entre ellos Ciudad sin corazón. Pero al año siguiente, en 1998, durante las XXI Bienales Internacionales de Poesía, en Lieja, tengo oportunidad de tomar contacto con los autores de una exigente y lograda Antología de la literatura árabe contemporánea, donde se lo incluye. Ellos me introducen en las dificultades de la transcripción por escrito, en nuestras lenguas, de los sonoros nombres árabes, cuya fonética cambia no sólo de país en país sino, incluso, de región en región. También me informan que Hiyazi nació en 1935, en una pequeña aldea del Delta del Nilo. Que cursó estudios en una escuela normal. Y que su origen modesto lo hizo muy sensible a la miseria del pueblo. Con un lógico resultado: se volvió militante socialista al mismo tiempo que poeta. Otros títulos de sus libros publicados son 
Aurés y No queda sino la confesión. Y Jean-Clarence Lambert me confirmará en París que nuestro amigo egipcio ya no reside allí, sino nuevamente en Egipto, en la sintomática ciudad de Heliópolis.

El mismo Hiyazi, en cambio, sólo me había dicho en Medellín que podía escribirle al legendario diario Al Ahram, en El Cairo, y me transmitió, sin proponérselo, por pura ósmosis, como acaso lo lograban los místicos antípodas de nuestras civilizaciones comunicantes, en los tiempos heroicos, una serena y profunda inmersión en la poesía como experiencia de vida y de lenguaje. Eso que, por aquí, hace ya tiempo que - por desdicha- andamos extrañando.

\section{Italia en mí}

(Respuestas a una encuesta sobre poesía italiana en Argentina efectuada por el Instituto Italiano de Cultura, Córdoba)

1. ¿Qué importancia atribuye a la influencia italiana en la poesía argentina contemporánea?

Suelo escapar, acaso instintivamente, y sobre todo en estas lides, de las grandes generalizaciones que me parecen, no solamente riesgosas, sino incluso peligrosas. Y, sin embargo, no puedo rehuir un hecho objetivo: siendo la nuestra una sociedad en gran medida aluvial, constituida por enormes masas de inmigrantes, se sabe que el aporte italiano fue el más cuantioso desde un punto de vista numérico. Quiere decir que hay casi una mitad de sangre italiana circulando por las venas argentinas. Eso explicó sin duda, en su momento, la vivísima presencia de su idioma, y hasta de sus felices dialectos, en nuestra propia identidad lingüística, sobre todo en la inmensa Buenos Aires pero también en Rosario, Mar del Plata y otras muchas ciudades y ámbitos de nuestro país. Y lógicamente también la presencia de un dejo, de un toque, de un matiz italiano en nuestras maneras de comportamiento. Durante largo tiempo vilipendiado cuando no negado, como ocurrió con el ciego rechazo a otras corrientes inmigratorias no sólo en los medios supuestamente patricios sino incluso, lo que habla bastante de nuestros resultados, en muchos de sus propios descendientes, compelidos a olvidar o negar a sus ancestros, si no la conciencia de su extraordinaria, luminosa historia cultural y estética, siempre presente en nuestras inteligencias más activas y despiertas, sí por lo menos el extraordinario desarrollo político, social y económico de la Italia de posguerra vino a modificar sin duda favorablemente esa perspectiva, en cuanto hace por lo menos a una visión macro, hoy con la dolorosa evidencia de que no fuimos capaces, nosotros mismos, los argentinos, de acompañar o aun emular como sociedad, como conjunto, tan magnífico ejemplo.

$\mathrm{Si}$, como creo, siguiendo a W. H. Auden, no hubo nunca un gran momento de la poesía culta, por más alquitarada o elitista que pareciese, que no estuviera misteriosa pero firmemente ligado, aunque fuera por oscuros meandros, con una gran lengua viva hablada por una comunidad, por un pueblo, me parece evidente que esa "italianidad", incluso la bellamente dialectal, infusa en nuestro uso de la lengua, en nuestra propia e ineludible manera de emplear el castellano, no podía dejar de manifestarse en la mejor poesía escrita aquí. Y no sólo por un contacto profundo con la gran poesía italiana sino también, intuyo, por ese yacimiento vivo, orgánico, activo de "italianidad” en nuestra lengua hablada, no sólo escrita. 
2. ¿Cuáles son los autores italianos más leídos, traducidos y publicados en nuestro país?

Nuestra carencia de estadísticas es, de algún modo, sintomática. Aunque, de todos modos, lo cuantitativo no me parece que deba ser predominante en estos dominios. Me ha tocado vivir, casi desde niño, algunos momentos sobre los cuales puedo dar testimonio. A la unánime sombra comprensiblemente ineludible de Dante, después de la primera guerra mundial se seguían traduciendo en nuestro medio los poetas italianos, no tan profusamente ni siempre en la dirección que uno hubiera preferido. Que por entonces se difundiera acaso más a D’Annunzio que a Leopardi no era menos sorprendente, pero no menos revelador, que al mismo tiempo circulara por ejemplo Trilussa, por citar sólo algunos nombres, por mí entrevistos al azar.

Durante la segunda guerra mundial, ya circulaban aquí más libros memorables del mejor humanismo italiano, de los cuales recuerdo por ejemplo a Ignazio Silone y el impar Elio Vittorini. En este último sobre todo, el tratamiento del lenguaje en su escritura literaria lo acercaba de una manera muy honda, y al mismo tiempo orgánica, a la intensidad y concentración de la poesía, que se encontraba asimismo muy presente, y de una manera no menos activa, en su muy fecunda labor de ensayista y polemista. Y en la posguerra, si había una vívida presencia en superficie de los narradores neorrealistas, comenzando por Vasco Pratolini, y también de los grandes realistas, encabezados sin duda por Alberto Moravia, de enorme repercusión para el momento, la gran poesía italiana comenzaba a ocupar con firmeza y solvencia, por su propio peso, un espacio cada vez más significativo, aunque nunca grandilocuente o estruendoso.

No mucho después, a fines de la década de los cincuenta y comienzos de la década de los sesenta, se produce por ejemplo una enorme influencia, intelectual y estética, de Cesare Pavese, que iba a perdurar por bastantes años. Su obra y su figura vinieron a enriquecer el panorama y las reflexiones de toda una generación de poetas, escritores e intelectuales argentinos. Casi al mismo tiempo, pero en realidad desde antes, la acentuada difusión de Ungaretti y poco después la de Montale, de alcances más profundos, menos evidentes, pero no menos intensos, contribuyeron a acentuar ese papel de acicate, de incentivo, que la gran poesía italiana del siglo XX venía ejerciendo también entre nosotros con peculiar y fecunda densidad, hoy acaso inimaginable en medio de la confortable barbarie de la planetaria sociedad del espectáculo.

Esa presencia puede detectarse en libros y antologías, sí, pero también en revistas y periódicos culturales de la época. De los cuales el gran número 225 de Sur dedicado a las letras italianas (Buenos Aires, noviembre-diciembre de 1953) constituya, acaso, a la vez una excepción y un paradigma. Y no sólo por el amplio espacio dedicado a la poesía, sino también - lo que resulta de algún modo evidente tan significativo como descriptivo- por la presencia de una reflexión cabal e iluminadora sobre la poesía, no sólo en sus criterios estéticos sino directamente culturales, sociales, humanistas, lingüísticos e incluso, por qué no, políticos en el mejor sentido. Un sendero por el cual Pier Paolo Pasolini, cada vez más apreciado entre nosotros, iba a avanzar con decisión, audacia e inteligencia. 
3. ¿Quiénes son a su juicio los traductores que más se han destacado en esa tarea?

No está en mi naturaleza, y muy especialmente alrededor de estos asuntos, imaginarme juez y parte. (Sólo me animaría a sugerir que, acompañando a mi hijo menor que estudia Letras, en estos mismos momentos estoy releyendo con gusto la digna traducción de La Divina Comedia de Ángel Battistessa. Y que me he sorprendido volviendo a descubrir qué respetuosa, qué solvente es la versión de Mitre). Estoy seguro que los nombres convocados a esta misma encuesta resultarán de algún modo una respuesta cabal a esa pregunta. Sólo puedo decir que hubo, hay y sin duda habrá, desde dentro o en contra de los condicionamientos orgánicos de cada momento histórico y cultural, apasionados y apasionantes traductores y lectores del italiano en nuestra literatura.

Hoy quisiera recordar tan sólo a uno, pero qué sintomático, a quien tuve la enorme fortuna de conocer en mi primera juventud, y que resulta en muchos sentidos paradigmático. Me refiero a Attilio Dabini, uno de los tantos luminosos escritores e intelectuales antifascistas italianos que se vieron obligados a exiliarse aquí, y que fue - como la mayoría de ellos — un ejemplo vivo de modestia y entereza, de coraje y lucidez (piénsese por ejemplo en gente del calibre de Rodolfo Mondolfo). Dabini sobrevivió traduciendo, con enorme calidad, y también escribiendo y publicando aquí su exigente obra personal, aunque el destino injusto no le permitió reintegrarse de pleno a la gran corriente viva de la cultura italiana que volvió a emerger allá en la posguerra.

Una cultura en la cual la poesía ocupa, prácticamente desde sus comienzos, un espacio esencial, fundacional. Un día, siendo yo un adolescente, me recibió en su casa y, probablemente como resultado de alguna tímida alusión mía, con la misma emoción que supo contagiarme me mostró algunos de sus tesoros más preciados, las primeras ediciones de ese poeta de la narración que es sin duda Elio Vittorini, totalmente corregidas de puño y letra por su autor, como testimonio de una insaciable voluntad de estilo, de una sed por la belleza que no hubieran sorprendido a Valéry, aunque quizá no dejara de llamarle la atención que un esteta tan exigente fuera, al mismo tiempo, indisolublemente, no sólo un gran humanista comprometido sino también incluso un héroe civil, un dignísimo y lúcido hombre público.

4. En su condición de traductor y poeta, ¿querría expresar qué ha significado para usted el acercamiento a los líricos italianos?

No hay en mis venas, que yo sepa, gota alguna de sangre italiana. Y sin embargo, siempre he sentido una instintiva, orgánica, irresistible e inefable afinidad con el arte y la vida, con la civilidad y el humanismo de la bella Italia. De tal modo, con tal intensidad, que me descubrí hablando y traduciendo el italiano sin haberlo estudiado nunca. Fenómeno de ósmosis, cuando no de posesión, de empatía más que de aprehensión, si nada llegó hasta mí por extraños vericuetos desde aquel Reino de las Dos Sicilias donde las dos penínsulas se confundieron, sólo atino a intuir que en el aire cosmopolita y políglota de la Buenos Aires que me tocó descubrir, como hijo mayor de inmigrantes gallegos, el italiano era una lengua viva, omnipresente, infusa. Y el azar, que es otro nombre de los dioses, puso en mi camino, ya desde los primeros tramos, algunos momentos privilegiados. 
Con Hugo Gola compartí el deslumbrado, apasionado descubrimiento del indeleble Cesare Pavese, que no mucho después de su trágica muerte iba a concretarse en la (compartida) selección y traducción de sus bellísimos ensayos, a los cuales pusimos como título El oficio de poeta (1957), y que iba a conocer reiteradas reediciones, prueba de su inusitada repercusión. $\mathrm{Al}$ año siguiente me encomiendan un libro de Gillo Dorfles, Constantes técnicas de las artes (1958). Y poco después, casi simultáneamente, no sólo una amplia antología de Giuseppe Ungaretti, Poemas escogidos (1962), también muy reeditada, y cuya factura constituyó para mí, además de una imborrable experiencia, una auténtica cantera, el mejor de los talleres que pudiera imaginarse, sino también los dos libros que abren y cierran la intensa, trágica vida de Pavese: Trabajar cansa, Vendrá la muerte y tendrá tus ojos, reunidos en un mismo volumen (1961), otra experiencia clave para mi formación, no apenas estética sino hondamente humana.

A partir de entonces, y a lo largo de toda mi vida, la gran literatura italiana no iba a dejar de poseerme. Recuerdo, de manera muy especial, a Campana, a Saba, al Montale indeleble, al Pasolini ineludible. Y a Guido Cavalcanti, y a Cecco Angiolieri. Y a Biagio Marin. Y a líneas de Leopardi y de Dante que uno lleva puestas, ya orgánicamente incorporadas. Pero son sólo algunos. Y una lista de nombres, por queridos e insignes que resulten, no va a revelar esta extrańa, comprensible afinidad, está presencia viva que en mí siento de la belleza y del humanismo de Italia.

5. Con anterioridad al siglo que recién ha acabado, ¿qué papel e importancia tuvo la poesía italiana en nuestra literatura?

He recordado a Mitre, un caso singular pero emblemático. Y podría mencionar también al poeta Pedro Juan Vignale, que en 1936 ya traducía a Ungaretti. Pero el azar de la memoria y mis propias lagunas no me librarían de ser injusto, de caer en dolorosas omisiones. Yo siento a lo italiano como una presencia viva, orgánica actuante, insisto, no como un mero dato o recurso bibliográfico. En tal sentido, no deja de preocuparme que, en el desolado panorama con que la masiva y planetaria sociedad del espectáculo está ahogando, mucho me temo que en gran medida, las antaño fecundísimas fuentes creadoras de la cultura europea (¿qué se ha creado de realmente significativo y original, por ejemplo en francés, después de Marguerite Yourcenar y el nouveau roman?), no hayan cesado de manar si es que no están cegadas. Y temo, insisto, que eso le pueda ocurrir incluso a la vivísima literatura italiana, que conoció tantas grandes estaciones poéticas.

Últimamente me he consolado pensando que todavía, por ejemplo en Portugal y en Grecia — claro que son países no narcotizados aún por el confort-, se continúa creando con exigencia y altura. Y mucho más me consuela descubrir, como lo vengo haciendo con fruición en los últimos tiempos, que en la Sicilia fecundísima y mestiza, tierra de vida y de lenguaje, después de Pirandello y Quasimodo, de Lampedusa y Sciascia, podemos encontrarnos aún, ayer nomás y todavía hoy, con obras tan resplandecientes y hondas, tan sabrosas y fecundas como las de Gesualdo Bufalino y Vincenzo Consolo, que leo y releo con encendido placer, por espontáneas $\mathrm{y}$ frescas, por maduras y sabias, por enriquecedoramente contagiosas. 
6. ¿No le parece que a algunos lectores puede sorprenderles el hecho de que, tratándose de una encuesta sobre poesía, usted mencione tan a menudo narradores o prosistas?

Puede ser. Pero a ellos les diría, precisamente con el lúcido Vincenzo Consolo, que "Hoy a muy pocos les interesa la poesía. Y ya no me refiero al género poético, sino a ese elemento indispensable que hacía de una novela una obra literaria de gran nivel. El público busca aturdirse con la anécdota y rechaza todo lo poético porque lo pone en contacto con una realidad más profunda que trata de evitar por todos los medios". Siempre he sentido que en el tratamiento del lenguaje como materia, en la escritura de muchos grandes narradores podía encontrarse mucha más poesía que en tantos supuestos cultores del género. $Y$ no me es inusual descubrir, aquí o allá, en el cuerpo vivo de grandes obras literarias en prosa (y no sólo aquellas que reflexionan a veces con luminosa intensidad sobre este asunto), líneas que me parecen resplandecientes concreciones de poesía. Cuando Bufalino dice, por ejemplo, "La luz, ¿qué quiere?”, en su magnífica Perorata del apestado, a mi modesto entender está mucho más cerca allí de la poesía que acaso en La amarga miel, su propio libro de poemas, o en los magníficos, tocantes aforismos de $E l$ malpensante, tantas veces humanísimamente líricos. Como entiendo haber dejado traslucir, mi idea de la poesía está mucho más cerca de considerarla una experiencia de vida y de lenguaje, una evidencia, antes que un mero género literario. Siempre tengo muy presente, cuando me toca reflexionar sobre estos asuntos, que fue nada menos que Dante quien, en La Divina Comedia, aludió tan explícitamente a la poesía como "la gloria de la lengua".

\section{Traducir a Rosalía}

Cuando yo era un niño, Rosalía de Castro podía ser en nuestra casa - un modesto hogar de inmigrantes gallegos, en el centro-sur de Buenos Aires - tan cotidiana como el pan y la sal. Su presencia y su palabra aparecían vivas, en el aire, de repente, sin haberlo previsto, casi como si formara parte del aire mismo que se respiraba, y en una casa donde no había demasiados libros nunca faltó uno suyo. Y sus versos emergían de pronto, en medio del fragor mismo de los días vividos, citados sin pensarlo, espontáneamente, como se escucha casi inconscientemente el arrullo de una fuente muy conocida, bien cercana, límpida y habitual.

Sólo mucho tiempo después, con los años y las ineludibles experiencias que acarrean, llegué a vislumbrar que aquella esencia casi inefable, de tan cotidiana, era también muchísimas otras cosas. La presencia de otra gente y de otra tierra. E, incluso, de otra infancia, vivida en otra parte, que vino a confundirse con la mía.

Pero también la presencia de una inmensa mujer, casi mítica, siempre de transida sonrisa melancólica, doliente (que luego llegaría, no sin cierta sorpresa, a identificar con la de mi propia madre, tan similar) que, de una honda tragedia personal —ser hija natural de un sacerdote, en el ámbito aldeano de una Galicia rural enclaustrada en la España decimonónica—, milagrosamente sublimada, había llegado a convertirse en paradigma de su pueblo. 
Un genio de la poesía y, en consecuencia, como bien dijo Dante, de una lengua que, gracias a su canto, volvía a erguirse, y a resurgir, después de siglos de inmerecido e involuntario oscurecimiento. Y también uno de los pocos románticos españoles que valga la pena. Todo eso consiguió Rosalía de Castro (1837-1885), acaso sin proponérselo, como dije de manera inefable. Y también lo imposible: ser hondamente ella misma, y ser también la voz misma de su pueblo, y ser (al mismo tiempo, inescindiblemente) una gran figura universal, universalmente reconocida y admirada.

Pero en mi infancia, como dije, ella era algo más fuerte que ningún convencionalismo o convencimiento intelectual. En una de las primeras actividades sociales de mi vida, al salir del patio de mi casa paterna para pisar el amplio vestíbulo de entrada al Centro Gallego de Buenos Aires, la presencia (para un niño, imponente) de su estatua no me la volvió fría, lejana o inaccesible. Seguía siendo una "llama de amor vivo" - como bien acuńó Juan de Yepes a su propia experiencia, que lo hizo llegar a ser San Juan de la Cruz - que, como el antiguo milagro de la poesía encarnada, como el inmarcesible logos griego, podía ser ella misma y ser los otros, los suyos y los de todas partes.

Por eso recibí con tanta emoción, mucho tiempo después, a comienzos de 1997, la invitación a traducirla. ${ }^{1}$ Era una nueva editorial argentina, y me propuso seleccionar una antología bilingüe, dejándome entera libertad. Como me ocurre en estos casos, entré casi en estado de trance y, durante un período que no sabría precisar pero sentí intenso y concentrado, me entregué a esa lengua que había mamado de los labios de mis padres, en mi infancia felizmente bilingüe, intentando en este caso por medio de mi propia ósmosis interna lo que siempre me pareció audaz, utópico, irrealizable: traducir una poesía lograda, por lo tanto ineludiblemente encarnada en su propio idioma, a otro.

La antología se concretó, e incluso tuvo buena repercusión, no sólo en la Argentina, mi país de nacimiento, o en Galicia, el país de mi sangre. Como bien dijo Paul Valéry, el exigente poeta francés, una de las mentes más lúcidas de este siglo en cuanto a reflexión literaria, todo poema resulta "esa oscilación prolongada entre el sonido y el sentido". Lo que, al cuajarse, tembloroso, cuando milagrosamente se da, lo convierte en un ser vivo de lenguaje, autónomo y soberano, cuya carne y sangre y aliento es el idioma en que está escrito. ¿Cómo animarse, entonces, a esa operación de alta cirugía, de cirugía de riesgo, que es intentar traspasarlo con vida de un idioma a otro?

Yo, que lo he intentado tantas veces, con diversos poetas de diferentes idiomas, confieso que es algo del todo inalcanzable. Lo más que uno puede llegar a conseguir, lealmente, son aproximaciones, versiones, acercamientos, rodeos. Que siempre, o casi siempre, deberán elegir inexorablemente entre sonido y sentido, entre la carne y el aliento del poema. Nunca se logrará traducir cabalmente eso que, precisamente, el poema logrado agrega de más a las palabras del lenguaje que ejerce. Pero, también, y con la misma honestidad, es humanamente imposible dejar de intentarlo. Más aún, es necesario tratar de hacerlo. (Por algo dijo, ese gran humanista latinoamericano que fue Pedro Henríquez Ureña, que "cada generación debe tratar de traducir a su Homero").

Traducir a Rosalía fue para mí una auténtica catarsis. Como si fuera la misma hierba viva de mi infancia, crecida en mi memoria, en este caso me dejé fluir de uno a otro de los dos idiomas en que me crié simultáneamente, tratando sin forzarlo de 
que el canto de Rosalía fluyera también — con sonido y sentido- en esta otra lengua que, después de todo, ella también empleó. (¿Cómo no recordar, aquí, que el mismo Pier Paolo Pasolini, quien comenzó escribiendo poemas en friulano, el idioma de su madre, siendo su autor no logró él mismo traducirse sino en prosa al italiano?).

Traducir del gallego al castellano fue, a la vez, para mí, en mí mismo, casi orgánicamente, tomar conciencia de sus límites y de sus riesgosas similitudes. (Algo que quizás, por otra parte, debe haber tenido que ver con mi temprana e ineludible vocación por la poesía). Nadie puede, humanamente, traducir nunca del todo eso tan inefable, ricamente expresivo, bello y logrado en sólo tres palabras: "Cómo chove miudiño". Y para dejar de algún modo bien plasmada mi conciencia de tal hecho, pedí que el título mismo del libro quedara en gallego.

Aunque podría hacerlo, yo no quiero juzgarme, en un sentido digamos apenas literario. Rosalía era, en mi infancia, como el pan y la sal, compartidos y accesibles, en la mesa familiar, en la mesa de todos. De algún modo, inefable, ahora también, también lo sigue siendo. Y eso resiste hasta a una traducción.

\section{Entrevista de Maria Antonieta Pereira para la revista Cerrados de la Universidad de Brasilia}

¿Cómo fue su primer contacto con la literatura brasileña?

Muy temprano, y casi contemporáneo con el insospechado descubrimiento de mi propia vocación por la poesía. Sin habérmelo propuesto, la noche anterior a cumplir mis diecisiete años, me encontré convertido en el miembro más joven de una legendaria revista argentina de vanguardia: Poesía Buenos Aires (1950-1960), que completó su importante labor de renovación teórica y práctica con una significativa tarea de difusión y traducción de los más destacados poetas contemporáneos. En ese ámbito, sin duda propicio, se manifestó muy pronto en mí un casi instintivo don de lenguas, que me permitió traducir poesía del francés y del italiano pero, sobre todo, del portugués. Desde un comienzo me sentí profundamente conmovido por el modernismo brasileño, que resonaba en mí de manera muy especial. Tanta que, ya en enero de 1956, publico en un diario mis primeras versiones de poemas de Carlos Drummond de Andrade. Que de inmediato me iban a dar la gran alegría de ponerme en contacto directo con él y, no mucho después, también con Murilo Mendes. Los dos fueron muy cálidos, muy afectuosos conmigo. Y, comenzando por ambos (aunque sobre todo por Drummond) comienzo una entrańable tarea de difusión del modernismo brasileño en castellano, que se ha extendido a muchos otros nombres, no sólo en poesía sino también en prosa, que iba a abarcar prácticamente toda mi vida, que no ha concluido y que, muy recientemente, casi completando un ciclo, acaba de permitirme concretar la mayor antología bilingüe de Manuel Bandeira que creo se haya editado en mi lengua: Estrella de la vida entera (Adriana Hidalgo Editora, Buenos Aires, 2003).

¿Cuál es su experiencia lingüística, como traductor de poesía brasileña, em termos de descobertas, alegrias e dificuldades?

La traducción de grandes poetas brasileños fue fundamental para mi propia formación. Hijo de gallegos, mi infancia fue bilingüe, y esa tarea me permitió en- 
troncarme con nuestros comunes orígenes del galaicoportugués, cuyos indelebles trovadores fueron sin duda un fundamento clave de la poesía en la península y de la lírica occidental. Pero hay algo más. Nacido en Buenos Aires, una auténtica Babel mestiza, donde se entrecruzan muchas lenguas, en mis primeros poemas se llegó a percibir "un sorprendente dominio de la materia verbal, en la que conjuga las conquistas de la poesía moderna en el terreno del lenguaje con el respeto de la estructura y del espíritu de la lengua cotidiana”. ¿Cómo sorprenderse de que me atrajera el modernismo brasileño, que supo ser auténticamente de vanguardia sin dejar de estar imbuido de la rica fecundidad del habla, de la música y de la canción popular? Al traducirlo me encontré por supuesto con muchas de las cuestiones que acarrea ese propósito con cualquier otra lengua. (No sólo por aquella "prolongada oscilación entre sonido y sentido" que el impar Paul Valéry percibió lúcidamente en el poema. Sino también porque coincido plenamente con mi compatriota Carlos Mastronardi: "Todo es traducible, excepto el lenguaje"). Pero, en este caso particular, en mis traducciones de la gran poesía brasileña, esos problemas se acentuaban por tratarse de una poesía de lenguaje, encarnada en su lenguaje vivo, actuante y fecundo. Y también por ser una lengua hermana, con los inevitables riesgos de homofonía. Como ya lo enuncia claramente Cervantes en el fundamental capítulo sexto del Quijote, traducir poesía es una empresa utópica. Pero irresistible. Y traducirlos me permitió leer a fondo, desde dentro, a los maestros brasileños, percibiendo dejando de la vital riqueza verbal y sonora la precisión y la exigencia, la temblorosa sabiduría de la dispositio.

¿En su opinión, se está formando un público lector de poesía brasileña en la Argentina?

En Argentina, las estadísticas no son nuestro fuerte. Y, mucho menos, tan especializadas. Incluso en términos generales, y no sólo para un determinado país en particular, los lectores de poesía parecen por lo general ser minoritarios. Pero como nosotros no medimos (o no deberíamos medir) estas cosas con el mismo parámetro que el mercado, podemos afirmar que son en cambio los lectores más intensos y más exigentes. Y los más duraderos, persistentes, devotos. Entre ellos, los lectores de poesía en la Argentina, la brasileña viene ocupando un lugar cada vez más digno. Sus grandes poetas son conocidos, y reconocidos. Su trascendencia y su proximidad son cada vez más evidentes. Y me alegra, me alegra, me alegra, después de tantos años, que mi trabajo haya contribuido en algo para ello.

¿Cuáles serían las principales semejanzas y diferencias entre la poesía modernista (de vanguardia, de comienzos del siglo XX) producida en el Brasil y en la Argentina?

Siempre lo he dicho: toda generalización es peligrosa. Con respecto a esta cuestión, me sentiría más cómodo hablando de un poema específico, hasta de una sola línea. Pero digamos que la vanguardia poética argentina tiene dos momentos en el siglo pasado. Para el martinfierrismo de la década del veinte, el contacto con la poesía brasileña fue esporádico. Salvo por iniciativas individuales, hubo que esperar hasta la década de los años cincuenta, con Poesía Buenos Aires, para que el modernismo brasileño, a través de sus principales nombres, comenzara a ser difundido cada 
vez más honda y ampliamente. Y no sólo el modernismo. No es casual que, desde un primer momento, Milton de Lima Sousa, a quien me he animado a bautizar como el poeta más desconocido del Brasil, fuera prácticamente uno más entre nosotros. Si las semejanzas se encontraban sin duda en la libertad adoptada para las formas expresivas, las diferencias respondían a las innegables, evidentes peculiaridades culturales de cada país hermano: más introvertidos, más intelectuales, más melancólicos acaso los rioplatenses, y más expansivos, más sensuales, más alegres generalmente los brasileños. Un poco como los paisajes de cada uno, que en este caso no eran sólo contexto, sino también intimidad. Y, acaso, esencia. De allí, de esa supuesta afinidad-diversidad, la mutua atracción, la mutua complementariedad de ambos dominios. Por otra parte, de proporciones diferentes en cada artista creador, y no sin asombrosos vasos comunicantes.

¿Como poeta, cuál es su evaluación de las producciones argentina y brasileña de la contemporaneidad?

Otra vez, el abismo de las generalizaciones. Y agravado, ahora sí, por las estadísticas. Hubo una época en que Rilke pudo decir: "Además no hay trescientos poetas". (Claro que se refería a los grandes poetas). ¿Quién podría afirmar, hoy, que conoce todo lo que se escribe como poesía en su país? Y si eso me ocurre con la Argentina, ¿cómo podría animarme a opinar del inmenso Brasil? Sólo dos o tres impresiones, acaso superficiales. Siempre me impresionó que los grandes patriarcas modernistas no parecieran competir entre sí, sino que más allá de las afinidades de escuela se reconocieran y trataran con fraternidad y exigencia, con reconocimiento y apoyo mutuo, pero limpia y honestamente, sin mezquinas segundas intenciones. (Me temo que, salvo honrosas excepciones, no suele ocurrir lo mismo en mi país). Quizá eso les permitió, a los brasileños, lograr a su vez una benéfica influencia colectiva, en su medio, entre su gente. Que pudo manifestarse a través de los grandes diarios que les abrieron sus páginas, dando lugar al sabroso y peculiar género de las crónicas. (Tampoco eso suele darse fácilmente entre nosotros.) Y hasta me parece haber visto que en Brasil se da una intensa vida creadora y cultural prácticamente en cada Estado (lo que serían nuestras provincias), pero que a veces queda como encapsulado en cada territorio, y que ese magnífico federalismo concretado a veces no se intercomunica entre sí. En la Argentina parece haber ocurrido lo inverso: no sólo la tradicional preeminencia de la capital, Buenos Aires, sino también el influjo arrasadoramente seductor y demagógico de los grandes medios audiovisuales han eliminado casi prácticamente toda personalidad provincial, incluso en los lenguajes. Me entusiasma también imaginar (a la vista de medios tan renovadores y activos como Rascunho en Curitiba, Poesia Sempre en Rio, Agulha en Fortaleza, Exu en Bahía, por ejemplo, o la vitalidad de las magníficas Jornadas Literarias de Passo Fundo, por citar sólo algunos, ya que mi conocimiento es limitado) que los jóvenes escritores brasileños son todavía capaces de crear, criticar y discutir en función de altas exigencias literarias, y no sólo para ubicarse más o menos favorablemente en el mercado. Hay allí lucha de tendencias, opiniones, apasionamientos, incluso excesos, es decir que hay realmente vida cultural, activa, orgánica, vigente. Me duele suponer que eso no está ocurriendo (o al menos, no lo suficiente para mi gusto) en Argentina. 
¿Tiene obras publicadas en Brasil? Envíe un poema de su autoría para los lectores brasileños.

Acaba de aparecer mi amplia Antologia pessoal, bilingüe (Thesaurus Editora, Brasilia, 2003), con brillantes traducciones al portugués de Anderson Braga Horta, José Jeronymo Rivera y José Augusto Seabra. De acuerdo con el criterio de la colección, se incluye también una introducción autobiográfica del autor, una selección de opiniones críticas internacionales y una completa bibliografía sobre mi trabajo como poeta y traductor. Con todo gusto acompaño a esta entrevista dos o tres poemas, en forma bilingüe.

¿Considerando los recientes diálogos entre Lula y Kirchner, usted cree en el fortalecimiento de un Mercosur Cultural, que estreche los lazos entre nuestros países?

Dentro de mis modestas posibilidades, me he pasado la vida traduciendo y difundiendo la gran literatura brasileña. Tengo la profunda convicción, casi constitucional en mí, de que es irracional que la mitad de un continente ignore olímpicamente a la otra mitad. Son muchas más las cosas que nos hermanan, que las que deberían separarnos. Después de todo, eso ya está en los sueños de nuestros padres fundadores, comenzando por Bolívar. Por otro lado, y ya en otro marco, creo que sólo fraternalmente unidos, pero por supuesto respetando nuestras peculiaridades, estaríamos en condiciones de enfrentar a los poderes que intentan continuar manteniéndonos balcanizados. (No es ninguna novedad lo de dividir para reinar). Desde una perspectiva macro es imposible no ver con buenos ojos tantos buenos deseos y tantas perspectivas de acercamiento y cooperación. Pero, en lo estrictamente cultural (para lo cual en gran medida coincido con Gilberto Gil en su criterio antropológico) me parece que las iniciativas verdaderamente fecundas y perdurables tienen que surgir $y$ florecer de abajo hacia arriba, que la legítima vida cultural es la que emana espontánea y libremente de nuestras comunidades, de nuestros pueblos, de nuestros creadores, y que sólo florecerán si allí se mantiene encendida la llama del amor y de la pasión por el conocimiento del otro, de los otros. Ninguna conferencia de ministros, ningún contrato ni ningún convenio, ningún acuerdo de gabinete pueden sustituir eso. Aunque las intenciones, insisto, y aún los proyectos y los pasos concretos, se dirijan en la buena dirección. Porque tampoco hay que olvidar que no sólo Kirchner visitó a Lula. No sé por qué me inquietan tanto esos encendidos elogios que al parecer le hizo Bush. Que no vaya a resultar otro abrazo del oso.

\footnotetext{
Nota

${ }^{1}$ Airiños, airiños aires, de Rosalía de Castro, selección, traducción y prólogo de Rodolfo Alonso (Ameghino Editora, Buenos Aires, 1997).
}

\footnotetext{
Alonso, Rodolfo

"La utopía traductora", en: El hilo de la fábula, Revista anual del Centro de Estudios Comparados, N ${ }^{\circ}$ Once. Santa Fe, Argentina, edicionesUNL, 2011, pp. 165-180.
} 